TARNOWSKIE STUDIA TEOLOGICZNE 36 (2017) NR 1, S. 165-182 http://dx.doi.org/10.15633/tst.2330

ks. Józef Młyński

UNIWERSYTET KARDYNAŁA STEFANA WYSZYŃSKIEGO

\title{
Miłość jest naszą misją. Rodzina w pełni żywa (World Meeting of Families Congress - Filadelfia, 22-25 września 2015 roku)
}

Miłość jest naszą misją. Oznacza to, że przez miłość Boga i siebie nawzajem osiągniemy pełnię życia. W tym kontekście Sobór Watykański II stwierdza, że każda rodzina jest Kościołem domowym, małą komórką większego Kościoła powszechnego. W czasach, kiedy rozprzestrzeniają się ideologie dokonujące redefinicji rodziny, refleksja na temat małżeństwa i rodziny wydaje się konieczna. W dniach od 23 do 27 września 2015 roku w Filadelfii, mieście braterskiej miłości (Philadelphia Maneto) odbyło się viı Światowe Spotkanie Rodzin (World Meeting of Families - Philadelphia 2015). Był to wyjątkowy czas zarówno w sensie naukowym, jak i duszpasterskim, w którym prezentowano najgłębsze aspekty teologiczno-pastoralne, religijno-moralne i socjologiczno-społeczne oraz antropologiczne małżeństwa i rodziny. Jako temat viII Światowego Spotkania Rodzin wybrano: Miłość jest nasza misją. Rodzina w petni żywa. Trwało ono pięć dni, podczas których odbył się także trzydniowy kongres. Został on schematycznie podzielny na sześć sesji plenarnych. Każda z nich rozpoczynała się ogólnym wprowadzeniem, a następnie zebrani wybierali panel, w którym chcieli uczestniczyć. Wykładów wprowadzających wygłoszono sześć, zaś wykładów w poszczególnych panelach w sumie 73. Prowadzone były w pięciu językach: angielskim, francuskim, włoskim, hiszpańskim i wietnamskim. Całość wydarzenia została zwieńczona mszą świętą pod przewodnictwem ojca świętego Franciszka, który wygłosił kazanie o pięknie i wartości rodziny we współczesnym świecie.

Miłość jest naszą misją

W pierwszym dniu Światowego Kongresu Rodzin wygłoszono trzydzieści wykładów. Wykład wprowadzający wygłosił bp Robert Barron, który 
podejmując zagadnienie Życie na obraz Boga. Stworzeni do radości i miłości, ukazał, jak rozumieć biblijne stwierdzenie, że człowiek (istota ludzka) został stworzony na obraz i podobieństwo Boga. Z kolei kard. Robert Sarah, podejmując temat Światło Rodziny w mrocznym świecie, wyjaśniał, że osoby Boże - Ojciec, Syn i Duch Święty - są jak rodzina, a człowiek stworzony na Boży obraz i podobieństwo odzwierciedla Trójcę Świętą przede wszystkim w swoim powołaniu - okazując miłość. Pismo Święte pokazuje, jak ciemność weszła na świat przez grzech pierworodny, spowodowała naruszenie tego powołania i pęknięcia $w$ relacjach do Boga, bliźniego. Wszystkie te konsekwencje są widoczne w świecie otoczonym przez ciemności. Kościół głoszący Jezusa Chrystusa jest jak światło, które świeci w ciemności. Otrzymując dar miłości przez Ducha Świętego, człowiek może kochać tak jak Jezus i pozostawać w komunii z Bogiem i bliźnimi. Rodzina chrześcijańska staje się głównym świadkiem tej miłości i jedności oraz źródłem wiary, nadziei i miłości we współczesnym świecie.

Kolejne wystąpienia podejmowały różnorodną tematykę. Arcybiskup J. Michael Miller zaprezentował zagadnienie Szkoła serca. Rodzice jako pierwsi katecheci. Rozpoczął od truizmu, że to rodzice są pierwszymi katechetami dla swoich dzieci, a zadanie to otrzymali na mocy dwóch sakramentów: chrztu świętego i małżeństwa, wraz z którymi otrzymali do wypełnienia misję przekazania wiary swoim dzieciom. W tym kontekście Christian i Christine Meertowie podjęli temat Święte pary (małżonkowie) - wzór na drodze do świętości. Rozpoczynając od frapującego pytania: „Czy małżeństwo może stać się źródłem prawdziwego szczęścia?”, ukazali, czego uczą nas przykłady świętych par połączonych sakramentem małżeństwa. Małżonkowie potrzebują moralności i duchowego kompasu, aby móc dostrzec prawdę i zrozumieć, czym jest miłość. Tym, którzy pozwalają działać łasce w sakramencie ich małżeństwa, należy pomóc znaleźć szczęście i radość i wskazać drogi doskonalenia małżeńskiego życia.

Diakon Harold Burke-Sivers, kolejny z prelegentów, podjął zagadnienie Maria z Nazaretu. Pierwsza Uczennica i Matka Odkupiciela, zachęcając do naśladowania w życiu rodzinnym wiary Maryi i jej zgody na wolę Bożą. Natomiast dr John S. Grabowski w referacie Po drugiej stronie Góry Synaj: wzrastać w cnocie dokonał próby udzielenia odpowiedzi na pytanie: „Dlaczego chrześcijanie powinni kształtować swój charakter?”, dochodząc do wniosku, że cnota uczy wartościowego postępowania i pomaga w osiągnięciu zbawienia. Kontynuatorem tej aksjologicznej myśli był wykład dr. Yves’a 
Semena pt. Czy społeczeństwo może istnieć bez rodziny. Prelegent wskazywał, dlaczego rodzina powinna mieć uprzywilejowane miejsce w społeczeństwie. Małżonkowie w rodzinie mogą się zrealizować jako osoby oraz przyczynić się do budowania prawdziwie ludzkiego społeczeństwa, które domaga się istnienia rodziny. Równie istotnym elementem trwającej debaty był wykład Terrence D. Griffitha pt. Rodzina $w$ mieście. Obawy rodzin żyjących $w$ mieście (miejskich). Zasygnalizował on, iż rodzina żyjąca w mieście stoi w obliczu pewnych wyzwań zaklasyfikowanych do konkretnych obszarów, takich jak: finanse, opieka zdrowotna i edukacja. Niewątpliwie mają one pozytywny, ale też i negatywny wpływ na jej rozwój.

Prokreacja jako współtworzenie: duchowość dla rodziców to wykład wygłoszony przez dr. Josepha Atkinsona, Nancy Atkinson i Jennifer Anne Bissex, którzy stwierdzili, że rodzina nie jest dla tchórzliwych, ale dla wszystkich, którzy chcą pracować dla zbawienia w Chrystusie. Bóg wzywa bowiem rodziców, by brali czynny udział w przekazywaniu Bożego podobieństwa. Dlatego warto zastanawiać się, jak w codziennym życiu realizowane są dary Boga, którymi obdarowani zostali małżonkowie, oraz jaki jest ich owoc. Jest to Radykalne wezwanie. Powołanie do życia zgodne $z$ wola Boga, jak przekonywał kolejny prelegent ks. Luis Granados. Natomiast abp Socrates B. Villegas w swojej prelekcji Jeden pierścień, aby wszystkimi rządzić. Przymierze małżeńskie wskazał, że małżeństwo jest kolebką, w której dzieci są przynoszone do chrzcielnicy, Kościół zaś to Mistyczne Ciało Chrystusa, w którym małżonkowie wprowadzają dzieci do życia kolejnymi sakramentami: pojednania, Eucharystii oraz namaszczenia chorych. W tym kontekście Brian Barcaro, Danielle Bean oraz Robyn Lee podkreślili także rolę przygotowania do małżeństwa w okresie narzeczeństwa. Podejmując temat: Doką zmierza ten związek? Randkowanie jako rozeznanie, wskazali, co jest celem randki, co oznacza „rozeznanie”. Było to ciekawe ujęcie tematu, gdyż niewiele osób zdaje sobie sprawę z tego, że rozeznanie na randce jest częścią procesu przygotowania do małżeństwa. Natomiast dr Gregory i Lisa Popcakowie w prelekcji Zobacz, jak oni się kochaja. Rodzina $i$ wiara zaprosili słuchaczy do podjęcia refleksji nad pytaniem: „Czy chciałbyś przeżyć jeszcze bardziej radosne, wzruszające i pełne łaski życie rodzinne?”. Aby pomóc w odpowiedzi i później w realizacji pragnień podzielili się praktycznymi pomysłami odnośnie do zmiany życia rodzinnego, proponując opanowanie pięciu podstawowych nawyków, które pomagają doświadczyć miłości pochodzącej z serca Boga. 
Kopanie w godność. Promowanie godności osoby ludzkiej to kolejny wykład, wygłoszony przez prof. Terese Stanton Collette, w odpowiedzi na przekonanie niektórych ludzi o tym, że godność człowieka jest pojęciem nienadającym się do podejmowania w dzisiejszym świecie. Do tej problematyki nawiązywało również wystąpienie Terry Polakovic, ukazujące Szczególne miejsce kobiety $w$ rodzinie, $w$ Kościele $i w$ świecie. Prelegentka przypomniała, że jeszcze przed św. Janem Pawłem II termin „geniusz kobiety” został opisany św. Edytę Stein, genialnego naukowca, karmelitankę i męczennicę z Auschwitz. Natomiast ks. Jean-Baptiste Edart, Jorge Mario Quiceno Nieto, Duber Astrid Zabala Vera i Mary Elizabeth Sperry w prezentacji Biblia. Księga dla rodziny, a światło dla świata przypomnieli, że słowo Boga jest źródłem światła i nadziei dla wspólnoty wiernych na świecie i w domu. Zachęcali zatem uczestników do refleksji nad biblijnym modelem rodziny, po to, aby znaleźć sposoby dzielenia się słowem Bożym i wykorzystania Pisma Świętego do uzdrawiania relacji rodzinnych. Z kolei prof. Hellen Alvare, podejmując problem Płodność chrześcijańskiej miłości, podkreśliła istotę miłości pomiędzy mężczyzną a kobietą, która powinna otwierać także na miłość rodzicielską do dzieci. W kontekst jej analizy wpisał się kolejny wykład, Andresa i Kathii Arango: Blok konstrukcyjny (budowla) i kamień węgielny (fundament), czyli budowanie rodzinnej miłości przez $k a \dot{z} d y$ czyn. Będąc zaangażowani w dzieło nowej ewangelizacji, podzielili się osobistym doświadczeniem $z$ ich życia, inspirując słuchaczy do pomocy rodzinom w codziennych obowiązkach. Skupili się szczególnie na zagadnieniu szukania czasu na spotkanie z Bogiem, zachęcając rodziny zwłaszcza do modlitwy wspólnotowej, która jest najcenniejszym darem, pozwalającym doświadczyć Jego obecności. Natomiast bp Jean Laffitte w prelekcji Dał się dla Was. Eucharystia jako wzór dla rodziny zaprezentował, w jaki sposób Chrystusowe oddanie jest modelem dla przysięgi małżeńskiej i odpowiedzialności. Równie ważne wątki zawierała prelekcja zaprezentowana przez s. Mary of the Sacred Heart Gaes, s. Adelę Galindo, s. Reginę Marię Gorman i s. Ann Marie Karlovic, podejmująca temat Rozwijanie powołania w domu rodzinnym. Prelegentki stwierdziły, że świadectwo wiary rodziców i ich rodzicielskiej roli jest dla dzieci zaproszeniem do odkrywania dróg własnego powołania. Należy jednak młodym pomagać i wspierać ich, aby dostrzegli i odkryli osobiste powołanie w Kościele.

Troska o dzieło stworzenia (świat). Papież Franciszek a zarządzanie środowiskiem naturalnym to temat, który podjęli kard. Peter Codwo Appiah 
Turkson oraz prezydent Republiki Panamy Juan Carlos Varela. Prelegenci zaznaczyli, że etyczno-moralne znaczenie ekonomii i ekologii dla rodziny jest niezaprzeczalne. W dzisiejszych czasach rodziny mogą być bardziej narażone na trudności ekonomicznie $\mathrm{z}$ powodu braku godnej pracy oraz doświadczania skutków złego zarządzania środowiskiem naturalnym. Kolejni sprawozdawcy: o. Rafael Capo, Andrea Blanco, William Cardona, Rey Malave, Emmabel Malave dokonali opisu Latynoamerykańskiej rodziny $w$ wielokulturowym społeczeństwie. Patrząc na duszpasterskie wyzwania stojące przed rodziną w kontekście różnorodności kulturowej, przedstawili doświadczenie rodzin latynoamerykańskich z usA. Zobrazowali rodzinę, która wprowadziła w życie słowa „domowy Kościół”, opierając swoje codzienne doświadczenie na własnych wartościach kulturowych w wielokulturowym społeczeństwie. Dodatkowo podali wskazówki do pracy duszpasterskiej w kontekście wspomnianych wyzwań.

Kolejny wykład, wygłoszony przez dr. Timothy T. O’Donnella pt. Życie jako domowy Kościół, nawiązał do słów św. Jana Pawła II: „Rodziny bądźcie tym, czym jesteście”. W tym kontekście autor przypomniał podstawy koncepcji rodziny jako domowego Kościoła we współczesnym świecie.

Robert C. Jazwinski w swoim referacie Trzy kroki do uzdrowienia finansów omawiał trzy ważne kroki równowagi finansowej w każdej rodzinie: jak zarządzać dochodami budżetu rodzinnego, jak inwestować nadwyżki oraz jak rozpoznawać początki problemów z finansami rodziny. To jednak nie wystarczy, bo ważniejsze jest, aby odpowiedzieć sobie na pytanie: Co jest celem moich wysiłków ekonomicznych? Czy tylko osiągnięcie pożądanego poziomu życia, a może wychowanie dzieci lub zapewnienie sobie godnego życia na emeryturze? Czy przy tym wszystkim stać mnie na wspieranie organizacji charytatywnych? Dlatego też Christine Codden w referacie „Byłem głodny...” Odpowiadanie na materialne i duchowe potrzeby rodziny w lokalnej parafii wskazywała, że wzmocnienie małżeństwa i życia rodzinnego w obecnej kulturze domaga się tworzenia „rodziny rodzin”, tak aby parafie mogły towarzyszyć i pomagać rodzinie na każdym kroku. Natomiast dr Janet Smith w prelekcji Kochając starszych mówiła o potrzebie uczenia się cierpliwości wobec osób w podeszłym wieku.

Ignatcio Ibarzabal, dr Cristian Conen, prof. Paola Delbosco i ks. Fabian Baez w refleksji Rodziny - dar dla społeczeństwa przypominali, że rodzina, pozostając ważną, cenioną przez Ewangelię drogą praktykowania miłości i wielkoduszności, zajmuje istotne miejsce w społeczeństwie. Umiejętność 
dawania przygotowuje ludzi do lepszych interakcji, poprawiając każdy aspekt życia ludzkiego, nawet kwestie finansowe. Niestety rodzina nieustannie musi się zmagać $\mathrm{z}$ wieloma problemami, których źródła są różnorodne. Jednym z nich są zmiany demograficzne, które wpływają na życie rodzinne. Na to zagadnienie zwrócili uwagę dr Andreas Salazar, dr Villamor Vital oraz Gerard-Francois Dumont w prelekcji Rodzina a dynamika demograficzna na świecie.

Michele Boulva w prezentacji Dom niepodzielony: Chrystus jako Zjednoczyciel zrekonstruowanej rodziny wskazywała, że w czasach nowej ewangelizacji zrekonstruowane rodziny są zaproszone do oparcia się na Jezusie, jedynej drodze do szczęścia, aby sprostać wielkim wyzwaniom, jak i radościom podczas wypełniania swojej misji i chrześcijańskiego powołania, jakim jest wychowanie „świętych uczniów”. W to zagadnienie wpisał się także kolejny wykład, ks. Dempseya Rosalesa-Acosty: Boża lektura: modlitwa $z$ Pismem w łączności z żywym Bogiem. Lektura Biblii została wskazana jako fundamentalne narzędzie dla współczesnej chrześcijańskiej rodziny służące wzmocnieniu więzów miłości pomiędzy członkami rodziny w stałej relacji z żywym Bogiem. W tym kontekście ks. Renzo Bonetti, ks. Nicky Lee, Sila Lee, dr Alessandro Sona oraz ks. Tory Baucum w prezentacji Rodzina - domowy Kościół: droga ewangelizacji i ekumenizmu zwrócili uwagę, że rodzina jest uprzywilejowaną drogą ewangelizacji i szkołą ekumenizmu. Wiele małżeństw katolickich podejmuje współpracę z małżonkami innych wyznań, tworząc wspólne programy pomocy rodzinie. Dzięki ich zaangażowaniu i współpracy udaje się także dotrzeć do niewierzących, którzy $\mathrm{z}$ radością przyjmują dar wiary.

\section{Rodzina w pełni żywa}

W drugim dniu Światowego Spotkania Rodzin słuchaczom z różnych krajów przedłożono do wysłuchania kolejne 32 wykłady o tematyce rodziny. Pierwsza prelekcja wprowadzająca, którą wygłosili dr Juan Francisco de la Guardia Brin oraz Gabriela N. de la Guardia, dotyczyła ważnego współcześnie tematu - Dar Boga: znaczenie ludzkiej seksualności. Prelegenci wskazali, że fakt bycia stworzonym na obraz Boga ma wielki wpływ na cel naszego życia. Kiedy zrozumiemy, że stworzenie ma wymiar duchowy, nasze postrzeganie siebie, innych oraz całego dzieła stworzenia ulegnie zmianie. Ta prezentacja łączyła teologię i dane naukowe w celu przywołania 
racjonalnych argumentów uzasadniających, że każdy człowiek jest powołany do życia, „dając siebie” w małżeństwie czy w celibacie. Kolejny wykład, dr. Scotta Hahna pt. Powrót do Edenu: Odkrycie przymierza Boga zludźmi, podkreślił, że w całej Biblii można dostrzec pewną klamrę tematyczną, pomagającą zrozumieć sens przymierza w Piśmie Świętym i jego wyjątkowość na tle różnego rodzaju umów. Biblia rozpoczyna się opisem stworzenia mężczyzny i kobiety $(\operatorname{Rdz} 1,26-27)$, a kończy wizją będącą ukoronowaniem historii zbawienia - „ucztą weselną Baranka” (Ap 19, 7-9). Dlatego pierwotną formą, w której ludzkość realizuje „obraz i podobieństwo Boże”, jest związek małżeński pojmowany z Bożej perspektywy jako przymierze. Doktor Alvaro Sierra z kolei w referacie Jedno Ciało: małżeństwo jako wzór dla Kościoła i Kościót jako wzór dla małżeństwa dokonał porównania małżeństwa i rodziny do wspólnoty Kościoła, wskazując na potrzebę dbania o sferę duchową rodziny. Natomiast Erika Bachiochi, omawiając temat Bez związu? Odpowiedź na „kulturę przelotnych znajomości” stwierdziła, że choć może się wydawać się, że obecnie kultura „ordynarności” zastąpiła zaloty, to jednak są oznaki świadczące o zmianie. Okazuje się, że wbrew ogólnym stwierdzeniom, w rzeczywistości mniej osób pozostaje w przelotnych związkach, mniej też odczuwa w nich radość. Pomimo to „kultura przelotnych związków” znajduje licznych zwolenników i zdołała już stworzyć próżnię w związkach międzyludzkich. Prelegentka starała się także wskazać młodym mężczyznom i kobietom drogi do trwałej i pełnej miłości.

Doktor Janett Smith, przedkładając temat Wyprzedzając swój czas. Profetyczny charakter „Humane vitae”, stwierdziła, że Paweł vi był odważnym człowiekiem, decydując się na podtrzymanie nauczania Kościoła o tym, że każdy akt małżeński musi zachować swoją moc prokreacyjną. Jeśli obecna kultura powszechnie zaakceptuje użycie antykoncepcji, to sama kultura zostanie zniszczona, a skutki tego będą katastrofalne. Ci, którzy respektują prokreacyjną moc aktu małżeńskiego, są szczęśliwi. Otwierają się na Bożą Opatrzność i prawdziwą miłość dla innych w życiu i społeczności. Lucia Baez Luzondo, podejmując temat o tytule Wolny dla bycia wiernym? Wolność religijna a rodzina, mówiła, że do istoty bycia człowiekiem należy wolność wyboru swojego losu. Człowiek otrzymał od Boga wolność wyboru oraz wrodzone wezwanie do życia w otoczeniu pełnym miłości. To wezwanie jest oparte na małżeńskiej jedności mężczyzny i kobiety, jako fundamencie rodziny. Rodzina jest ważną społecznością, która ma umożliwić osobistą wolność wiary i życia zgodnie z bosko-ludzkim przymierzem. Życie zgodne 
z naszą naturą pozwala nam wypełnić nasz ludzki los, a wolność czynienia tego jest naszym niezbywalnym prawem, które musimy chronić. Z kolei dr Andrew W. Lichtenwalner, ukazując wartość rodziny w tezie Święta Rodzina a świętość rodziny, zaznaczył, że chociaż Święta Rodzina jest stawiana za wzór dla wszystkich chrześcijańskich rodzin, to istnieje pokusa, że uczyni się z niej abstrakcyjny ideał. Można zapomnieć, że jej świętość była oparta na ciągłym poddawaniu się woli Ojca, pośród zmagań i radości. Dlatego jest ona wskazana jako wzór domowego Kościoła.

Każdy człowiek został powołany przez Boga do pełnienia odpowiedniej roli w społeczeństwie. Ten temat podjęła s. Agnes Mary Donovan, referując zagadnienie Nie ma wakacji od powołania: dostrzeganie Bożego wezwania w swoim życiu. Prelegentka zauważyła, że o ile dużo mówi się o odkrywaniu życiowego powołania, o tyle nie podejmuje się refleksji nad tym, co się dzieje potem, kiedy już podejmiemy życie zgodne z tym powołaniem. Czy gdy już zawarliśmy związek małżeński, rozpoczęliśmy życie kapłańskie lub zakonne albo zdecydowaliśmy się pozostać singlem, kiedykolwiek myślimy: Co teraz? Skąd wiem, czego Bóg ode mnie żąda? Po podjęciu definitywnej decyzji nie ma miejsca na niezdecydowanie dotyczące Bożej woli w codziennych decyzjach. Przywołując św. Ignacego Loyolę, przypomniała, że chociaż świat uważa swobodę za wyzwolenie, to tym, co naprawdę wyzwala w powołaniu, są więzy miłości z Bogiem i z drugim człowiekiem. Trzeba zatem uczestniczyć w Tworzeniu kwitnącej kultury małżeńskiej, jak zaznaczyli kolejni prelegenci: prof. Robert P. George i Sherif Girgis. Omówili oni naturę i przyczyny zawierania małżeństwa oraz istotną rolę ustanowienia, podtrzymywania i rozwijania tradycji rodzinnych i małżeńskich, które mają wpływ na kulturę. Wyjaśnili, dlaczego taka kultura jest możliwa tylko tam, gdzie prawo i polityka społeczna oparte są na zdrowym rozumieniu, czym jest małżeństwo. Jest ono bowiem czymś więcej, niż tylko romantycznym czy domowym partnerstwem. Istnieje zatem ciągła potrzeba celebracji misji miłości. Dlatego Celebrowanie Królestwa: miłość małżeńska i celibatowa było tematem wykładu kard. Gerarda Cypriena Lacroix, który podkreślił, że Boży plan wobec nas jest bardzo piękny. Bóg mówi nam nie tylko, kim jesteśmy, ale także jak powołanie każdej osoby do miłości może być przeżywane, zarówno w małżeństwie, jak i w celibacie, dla Bożego Królestwa. W dzisiejszej bardzo zseksualizowanej kulturze interesujące jest odkrycie, jak Pan prowadzi nas do zdrowych i świętych związków. Pary małżeńskie i osoby pozostające w celibacie mają wiele do zaoferowania współczesnemu 
światu. Myśl ta została rozwinięta przez s. Paulę Jeanę Miller w prelekcji Miłość celibatowa: świadek Królestwa Bożego. Prelegentka indagowała słuchaczy pytaniami, na które starała się także podać odpowiedzi: „Czy kiedykolwiek zastanawialiście się, dlaczego osoba konsekrowana jest nazywana «oblubienicą Chrystusa» lub dlaczego biskup nosi pierścień symbolizujący więź z jego ludem?”. „Dlaczego nazywamy księdza «ojcem», a zakonnicę «matką»?". „Jeśli wszystkie trzy powołania chrześcijańskiej miłości są «małżeńskie», to dlaczego księża i osoby zakonne ślubują życie w czystej, celibatowej miłości?”. „Dlaczego księża, osoby konsekrowane oraz pary małżeńskie potrzebują siebie nawzajem, aby w pełni być świadkami małżeńskiej miłości Chrystusa do Jego Kościoła oraz Bożego Królestwa miłości”. Natomiast s. Sara Butler, podkreślając biologiczny wymiar organizmu ludzkiego i dokonując analizy funkcji seksualnej Uzupetnianie się płci. Przeszkoda czy dar?, rozpoczęła od oceny książki pt. Mężczyźni są z Marsa, a kobiety są z Wenus. Teorie, które mają na celu wyjaśnić różnice pomiędzy płciami albo im zaprzeczyć, zawsze zdają się przyciągać uwagę. Niektóre współczesne teorie feministyczne podkreślają identyczność, a odrzucają uzupełnianie się płci. Utrzymują, że męskość i kobiecość są społeczno-kulturowymi tworami, niezwiązanymi z czyjąś cielesną kondycją jako mężczyzny czy kobiety. Trzeba zatem zastanowić się, jak nauczanie Kościoła odpowiada na te teorie poprzez obronę uzupełniania się płci? I dlaczego Kościół uważa je za wartość, jako Boży dar służący realizacji zadań w rodzinie.

Miłość poprzez pokolenia. Dziadkowie i pradziadkowie to kolejny wykład, wygłoszony przez Catherine Wiley, Phillipa Butchera i Michaela La Corte’a. Prelegenci ukazywali wartość przekazywania wiary, tradycji chrześcijańskich i modlitwy oraz to, jak poprzez pokolenia miłość rodziców i dziadków odzwierciedlała cudowny Boży plan wobec nas wszystkich. Równie istotnym elementem harmonii $\mathrm{w}$ rodzinie jest przebaczenie. Temat ten: Ulepszanie domu: przebaczenie a życie rodzinne zaprezentował dr Daniel I. Mark, który mówił, że Biblia i nauczanie religijne prowadzą nas do ideału życia rodzinnego, chociaż wiemy, że życie rodzinne bywa trudne. Przywoływał także biblijne przykłady zerwania więzi rodzinnych, aby w nich szukać dróg do naprawiania, z Bożą pomocą, relacji małżeńskich i rodzinnych. Kontynuacją tego zagadnienia był referat ks. Livia Meliny „Ojcze, wybacz mi... Rodzino, wybacz mi”. Rodzina a sakrament pojednania. Wskazał, że wybaczanie jest ważne we wszystkich związkach - nikt $\mathrm{z}$ nas nie jest ideałem, często niszczymy nasze relacje z Bogiem i innymi. Jak możemy reagować, kiedy zraniliśmy 
innych lub sami zostaliśmy zranieni przez nich? Co z czynami, które wydają się być niewybaczalne? Wskazówka jest jedna: należy odkryć uzdrawiającą moc sakramentu pojednania, który może pomóc odnowić relacje i stać się początkiem nowego życia. W ten sposób także spowiedź będzie zapraszać do okazywania sobie miłosierdzia w rodzinie, tak aby stała się ona domem miłosierdzia. Podsumowaniem tych wykładów była prelekcja kard. Luisa Antonia Tagle Rodzina. Dom zranionego serca. Każdy zmaga się z bolesnymi sytuacjami, takimi jak: samotność, bieda, niepełnosprawność, choroba lub uzależnienie, bezrobocie. W naszych rodzinach i Kościołach musimy rozmawiać z każdym z miłością i wsparciem, pomagając tym, którzy są w wielkiej potrzebie. Kościół - także jako nasza matka, pocieszyciel i przewodnik - jest rodziną, rodziną wiary. Jak możemy pomóc sobie nawzajem? I jak Kościół może nieść każdemu z nas uzdrawiającą moc Bożej łaski? To tylko niektóre pytania podejmowane przez prelegenta, nawołującego do wzrastania $\mathrm{w} \mathrm{mi-}$ łości, udziału w charytatywności, modlitwie, duchowej dyscyplinie, lekturze Pisma Świętego oraz w życiu sakramentalnym i liturgicznym. Natomiast dr M. Craig Barnes, pani pastor Kimberly van Driel oraz o. Thomas Joseph White w wykładzie Ciało i Krew: miłość przymierza a znaczenie wcielenia Syna Bożego ukazywali ideę przymierza w historii zbawienia oraz zachęcali, jak zastosować umowę przymierza we własnym życiu. Swój naukowy wywód mówcy rozpoczęli od przywołania starotestamentalnej relacji pomiędzy Bogiem a Izraelitami opartej na przymierzu, a skoncentrowali się na Nowym Testamencie i wcieleniu, przez które Syn Boży z miłości do nas przyjął ciało i stał się człowiekiem, przypieczętowując swoją krwią zawarte z nami przymierze. Zachęcali do tego, by wykorzystywać biblijną ideę przymierza jako model życia rodzinnego, po to, by trwać w związku sakramentalnym.

Wykład Budowanie sprawiedliwego społeczeństwa. Katolicka nauka społeczna w twoim życiu autorstwa prof. Helen Alvare ukazał sprawiedliwość społeczną jako naturalne następstwo miłości rodzinnej. Natomiast ks. Kevin Gillespe, omawiając zagadnienie Dawanie siły naszej słabości. Uzależnienie a religijność wskazał, w jaki sposób uzależnienie wpływa na ludzkie ciało, życie i rodzinę. Destrukcja człowieka i rodziny obejmuje wszystkie płaszczyzny jego bytowania: fizycznego, emocjonalnego, społecznego, moralnego oraz duchowego. Dlatego formą pomocy wyjścia z całej gamy uzależnień (zarówno psychologicznych, jak i fizjologicznych) jest pielęgnowanie sakramentalnych praktyk, takich jak: Eucharystia, sakrament pojednania oraz postawy religijne (pobożne modlitwy, praktyki medytacyjne oraz duchowe 
ćwiczenia), które mogą przynieść uzdrowienie i dać nadzieję jednostce i rodzinom zmagającym się z uzależnieniem. Z kolei Kathy Hendricks, s. Patricia M. McCormack, Damon Owens i Matthew Pinto podjęli temat Akt świętej równowagi: zapracowane życie a rodzinna duchowość. Ich zdaniem na sercach rodziców i dziadków ciążą dzisiaj trzy pytania: Jak zrównoważyć wiarę, rodzinę i pracę? Jak żyć w zseksualizowanym świecie z jego wyzwaniami, a jednocześnie podążać za wezwaniem do bycia świętym? Jak kultywować bogatą, lecz praktyczną rodzinną duchowość? Paneliści odpowiadali na te pytania z czterech różnych perspektyw, dzieląc się praktycznymi radami dotyczącymi rozwoju duchowego w rodzinie. Natomiast Janice Bentona w wykładzie Przyjmowanie trudów i błogosławieństw niepełnosprawności podjęła zagadnienie duchowej troski parafii o ich członków dotkniętych niepełnosprawnością.

Curtis Martin, w referacie Co jest nowego w nowej ewangelizacji?, poprzez opowiadania i ilustracje zachęcał słuchaczy, aby zauważyli, że istnieje wiele sposobów znajdowania w Kościele nowej radości i wzrostu duchowego. Ponadto stwierdził, że wiara katolicka jest dla każdego kluczem do stania się tym, kim powinien być. Natomiast dr Kyle A. Beiter, kard. Willem Jacobus Eijk oraz dr Gianna Emanuela Molla, podejmując zagadnienie „Z głębokości wołam do Ciebie Panie”. Boleść niepłodności, przyznali, że niepłodność może być dla par ciężkim krzyżem. Jednakże, jeśli wszystko odda się w ręce Boga, zawsze jest nadzieja i szansa na wielkie dobro. Prelegenci wyjaśniali także, jakie etyczne i medyczne możliwości mają rodziny zmagające się z niepłodnością oraz podpowiadali, w jaki sposób społeczności, krewni, sąsiedzi, parafie oraz przyjaciele mogą wesprzeć niepłodne pary. Zachęcali ponadto do odwoływania się do pośrednictwa św. Gianny Beretty Molli, orędowniczki par niemogących począć dziecka. Kolejny prelegent, dr Miguel Angel Dominguez Mena, w referacie Szpital polowy. Odpowiedzialność Kościoła za uczynienie Chrystusa uzdrowicielem obecnym $w$ rodzinie $i$ na świecie podkreślał, że historia Łazarza z Ewangelii św. Jana może nas nauczyć, że Jezus Chrystus żyje i chce być uzdrowicielem naszego społeczeństwa. Oczekuje jednak naszych dłoni, aby uczynić z nas narzędzia w procesie przywracania nadziei i życia, zarówno fizycznego, jak i duchowego.

W ramach wykładów zajęto się również zagadnieniem obecności Internetu we współczesnej w rodzinie. Dr Melissa Anderson w prelekcji Nawigacja $w$ sieci. Korzyści i wady bycia rodzina $w$ sieci uznała, że: Internet, aplikacje, media społecznościowe oraz e-czytelnicy są i pozostaną integralną częścią 
życia współczesnych dzieci. Pytaniem jest, jak rodzice mogą być obecni w sieci i kształtować rodzinny dialog dotyczący technologii. Przy pomocy humoru i Internetu dr Anderson zapoznawała uczestników z obecnymi badaniami nad mózgiem i technologią, nad tym, jak dzieci rozwijają wrodzoną zdolność podejmowania decyzji oraz wskazywała, jak używać tych informacji do podejmowania w rodzinie wyborów dotyczących technologii. Z kolei Noami Schaefer Riley w wystąpieniu Wspólnie wezwani. Małżeństwo międzywyznaniowe, omówiła problem różnic wyznaniowych w małżeństwie, wychodząc od faktu statystycznego, że w Ameryce dwa na pięć małżeństw są zawierane pomiędzy członkami różnych wyznań.

Kolejne tematy dotyczyły różnych trudności w rodzinie. Ksiądz John Paul Echert, ks. Antonio Lopez oraz dr Joseph White zwrócili uwagę na problem rozłąki (Siła rodziny w czasach rozłąki) wynikającej z czynników niezależnych. Zaznaczyli, że z powodu zobowiązań zawodowych, służby wojskowej oraz innych powszechnych we współczesnym świecie czynników wiele rodzin doświadcza długotrwałej lub okresowej rozłąki. Podkreślili teologiczne i religijne spojrzenie na siłę rodziny podczas okresów rozdzielenia jej członków oraz rolę tożsamości rodzinnej i wspólnych wspomnień w utrzymaniu rodzin w duchowej i emocjonalnej jedności, pomimo fizycznej odległości oraz zaproponowali praktyczne strategie i sposoby szukania wsparcia w tym trudnym czasie. Natomiast Rose Sweet w prelekcji Jestem $z$ Toba. Radzenie sobie $z$ rozwodem podkreśliła, że choć małżeństwo może i powinno wiele znaczyć, to jednak rozwody czasem się zdarzają. Bazując na 20 latach pracy z żyjącymi w separacji i rozwiedzionymi oraz żyjącymi w ponownych związkach, zaproponowała sposoby uleczenia zranionej rodziny poprzez zaufanie do Kościoła i do Boga. Inną raną, obok rozwodu, występującą w rodzinie może być przemoc. Dr Christauria Welland w podjętym referacie Kiedy rany pochodza z wnętrza. Przemoc domowa w rodzinie katolickiej wskazała, że przemoc domowa dotyczy jednej na trzy kobiety na świecie. Może się ona wyrażać w fizycznym i seksualnym molestowaniu, jak również w emocjonalnym wykorzystywaniu przez małżonka. Obietnica wzajemnej miłości zostaje zrujnowana, serca złamane, ciała i dusze poranione, a nadzieja znika. Dzieci narażone są na ryzyko powtarzania agresywnych zachowań rodziców. Referentka w dalszej części wykładu mówiła o różnych nastawieniach, szacunku i praktycznych technikach eliminowania przemocy w rodzinie.

Ważnym tematem sesji plenarnej było podjęcie przez Eldera D. Todda Christoffersona tematu Życie według planu Ojca niebieskiego: techniki 
jedności rodzinnej $z$ mormońskich domów. Christofferson podzielił się regułami i czynnościami, które jednoczą mormońskie rodziny na całym świecie, takimi jak: niedzielne nabożeństwo, rodzinna modlitwa, czytanie Pisma Świętego, cotygodniowy rodzinny wieczór oraz rodzinna historia. Uczestnicy zostali zapoznani z inspirującymi regułami oraz praktycznymi poradami budowania i podtrzymywania rodzin opartych na wierze, pomimo niesprzyjających warunków kulturowych.

W ostatnim wykładzie tej sesji Ron oraz Beverley Belgau podjęli zagadnienie Zawsze miej na uwadze osobę. Homoseksualność w rodzinie. Prelegenci rozważali, w jaki sposób katolickie rodziny mogą zareagować na odkrycie, że członek rodziny odczuwa pociąg do tej samej płci, że jest gejem lub lesbijką. Ron Belgau, katolik gej pozostający bezżennym, akceptujący nauczanie Kościoła, oraz jego matka Beverly Belgau podzielili się swoją historią wzajemnej akceptacji w granicach prawa Bożego. Opisywali także, jak katolicy powinni reagować na homoseksualnych przyjaciół lub członków rodziny, którzy albo przyjmują katolickie nauczanie o czystości, albo je odrzucają.

\section{Rodzina w doświadczeniu życia}

W trzecim dniu interdyscyplinarnej refleksji nad rodziną uczestnikom zaproponowano jeden temat wprowadzający oraz 15 tematów panelowych. Temat ogólny wygłoszony przez kard. Seana O’Malleya i pastora Ricka Warrena został zatytułowany Radość Ewangelii życia. Chrześcijańskie rodziny, zaznaczyli prelegenci, są wezwane do bycia fundamentem w naszym świecie, ukazywania człowiekowi światła i nadziei. W świecie pełnym cierpienia i smutku nasz największy świadek - rodzina - ma prowadzić do odważnej wiary i zaraźliwej radości, uosabiając w niej błogosławieństwa Chrystusa. Powinna to czynić, przyjmując Dobrą Nowinę, radość Ewangelii, zmierzając do całkowitego zawierzenia planowi, który Bóg wyznaczył dla każdej rodziny.

W ramach wystąpień panelowych patriarcha Jerozolimy Fouad B. Twal i dr Salvatore Martinez, odwołując się do radości Ewangelii w prelekcji Droga Krzyża, droga serca. Cierpienie, a rodzina, nakreślili obraz owej radości. Radość Ewangelii zawsze zawiera ludzkie doświadczenie cierpienia. Jesteśmy stworzeni do radości - nasze serca pragną jej, a spotykamy drogę krzyża. Krzyż nie może być usunięty z historii. Jezus przyszedł nauczyć nas, jak go dźwigać i nie poddawać się. W każdej rodzinie cierpienie musi mieć woń Zmartwychwstania; nie jest ono dla śmierci, ale dla życia. Krzyż jest 
najbardziej autentycznym dowodem naszej przyjaźni z Jezusem - ogołaca nasze serca i sprawdza jakość naszej miłości do Boga, nas samych i innych. Z kolei Alejandro Bermudez, Joseph i Gina Loehrowie oraz rabin Abraham Skórka w prelekcji Jak cenna jest rodzina. Porada papieża Franciszka: jak kochać? przedstawili, w jaki sposób słowa i czyny papieża Franciszka mobilizują do tego, aby miłość uczynić misją swego życia.

Natomiast Lacy Rabiedau w prelekcji Więzi rodzinne: jak posiłki, ceremonie, tradycje, pobożność i modlitwa tworza silna, zdrowa i petna radości katolicka rodzinę opisała wspólnotowe życie w rodzinie i wskazała, że nie należy się bać wychowania dzieci w wierze. Może się to dokonać przez takie przeżywanie w domu roku liturgicznego, które staje się radością dla całej rodziny. Aby tak się stało, istotne jest włącznie wiary we wszystkie aspekty życia domowego. Sue Muldoon, podejmując wykład na temat Miłość na krawędzi. Leczenie ran rozbitego związku, mówiła, jak reagować, gdy rodzina lub bliscy przyjaciele nas rozczarowują, i jak naprawić ból, który został zadany. Referentka odwoływała się do prawdziwych historii rodzin oraz obrazów z Pisma Świętego, aby wskazać drogi wiodące do przebaczenia, akceptowania siebie nawzajem. W trudnej sytuacji rodziny (rozpadania się związku) należy poszukiwać rozsądnych granic oraz praktycznych strategii, owocujących uzdrowieniem i duchowym pokojem zrodzonym po bólu.

Istotnym czynnikiem bytowania małżeńsko-rodzinnego jest - jak zaznaczyła dr Carolyn Y. Woo - piękne życie. W prelekcji Życie jest piękne. Głoszenie światu Miłości Chrystusa omówiła wartość pracy nad chrześcijańskim rozwojem albo rozprzestrzenianiem się chrześcijaństwa. Zadanie to często prowadzone jest w krajach misyjnych pośród braku pożywienia, opieki medycznej, edukacji, środków utrzymania czy sprawiedliwości, ale oparte jest w dużej mierze na wierze w Bożą Opatrzność. Trzeba zastanawiać się, jak współcześnie zastąpić roszczeniowe podejście do Bożej Opatrzności w społeczeństwach rozwiniętych, aby zachęcać ludzi do dawania siebie i do życia skoncentrowanego nie tylko na sobie, lecz także na innych. Natomiast prof. Stephanie Coontz, dr Marcellino D’Ambrossio, państwo Mitchel i Kathy Finleyowie - paneliści kolejnego wykładu: Małżństwo kiedyś i dziś. Oczekiwania $w$ stosunku do matżeństwa $w$ czasie narodzin narodu amerykańskiego przybliżyli uczestnikom historyczne spojrzenie na małżeństwo w kulturze amerykańskiej. Jako że amerykańskie doświadczenie małżeństwa znacząco ewaluowało w ciągu 250 lat, uznano, że warto zbadać ten rozwój oraz przybliżyć jego konsekwencje. By pozostać wiernym niezmiennemu 
rozumieniu małżeństwa, o którym mówi Kościół, należy ukazywać przykłady takich par, jak np. John i Abigail Adamsowie, będących inspiracją i wzorem życia małżeńskiego. Zdaniem prelegentów katolicka wizja rodziny, jako domowego Kościoła, stanowi fundament, na podstawie którego należy analizować obecne i przeszłe rozumienie małżeństwa oraz wyznaczać prognozy rozwoju małżeństwa i rodziny w przyszłości.

Sonia Maria Crespo, wygłaszając referat Komunikacja dla par, postawiła pytanie: Czy mężowie i żony naprawdę rozumieją siebie nawzajem? Przykładowo, żona może postrzegać coś, co mąż powiedział inaczej, niż to było jego zamiarem. Rozmowa kończy się wówczas złością obojga, bo żadne z małżonków nie potrafiło zakomunikować tego, co naprawdę myśli i czuje. Nieporozumienia małżeńskie mogą być rozwiązane, jeśli komunikacja jest bezpośrednia, ma charakter zachęcający oraz jest oparta na szacunku do drugiej osoby. Poprawa komunikacji między małżonkami skutkuje pogłębieniem ich wzajemnej miłości. Prelegentka próbowała ukazać, w jaki sposób rozmawiać w małżeństwie, aby żyć w pełnej wspólnocie miłości.

Kardynał Luis Antonio Tagle w kolejnym referacie Misja (nie)możliwa: wychodzenie naprzeciw innym $w$ autentyczny i efektywny sposób mówił, że różnorodność czyni życie kolorowym i bogatym. Skoro sami oczekujemy akceptacji naszych zdolności i talentów, to i my powinniśmy dostrzegać wyjątkowość, dary i predyspozycje innych. Skoro sami nie chcemy być szufladkowani, zastosujmy tę zasadę także wobec innych. Bazując na autentycznym dialogu, opartym na szacunku i miłości, możemy uniknąć podziałów, uprzedzeń, izolacji, a nawet przemocy. Takie postawy kształtują przyszłość całej ludzkiej rodziny.

Chris Stefanick w prelekcji na temat Kapłan, prorok, król. Żyjąc naszym powołaniem nadanym na chrzcie, ukazując wartość chrztu św., rozpoczął od stwierdzenia: „Bądź tym, kim jesteś! Każdy pragnie głębszego sensu, znaczenia oraz misji swojego życia. Nasza wiara dostarcza tego daru każdej osobie i każdej rodzinie. Jednakże to dopiero w kontekście życia rodzinnego po raz pierwszy poznajemy wielkość tego, kim jesteśmy i do czego jesteśmy powołani na tym świecie”. Referent podawał praktyczne rady, jak rodzice powinni przeżywać swoją tożsamość i jak ratować świat, póki na nim są. W tym kontekście dr Rebecca Vitz Cherico, omawiając zagadnienie Matki i ojcowie jako pierwsi nauczyciele wiary. Przekazywanie wiary dzieciom od niemowlęctwa po dorosłość, zachęcała do poszukiwania własnych sposobów przekazywania wiary dzieciom, przypominała też, że należy przy 
tym pamiętać o źródle wiary, którym jest Bóg. Nasza osobista wiara jest tak wielkim błogosławieństwem, że chcemy i powinniśmy ją przekazywać dzieciom, ukazując im jej atrakcyjność. Jednym ze sposobów jest budowanie radosnych i pięknych rodzinnych tradycji religijnych (łącznie z konsumpcją, czyli „eucharystią niedzielnego stołu”). Natomiast Simcha Fisher w prelekcji: "Idźcie": ewangelizacja a społeczeństwo globalne mówiła o wpływie katolickiej rodziny na społeczeństwo globalne. Jej zdaniem Boże prawa czynią nas bardziej sobą i porządkują ludzką egzystencję, dlatego katolickie rodziny są zapraszane do tego, aby pokazać światu wartość małżeństwa i rodziny zachowującej Boże prawo Dekalogu. Doktor Mary Hirschfeld podjęła temat Wspieranie wspólnego dobra poprzez swoje zakupy i wydatki. Indagowała słuchaczy: Ile współczesnemu człowiekowi potrzeba środków, ile to dostatecznie dużo? Jak równoważyć potrzebę dbania o nasze rodziny z chrześcijańskim nakazem pomagania tym, którzy są w potrzebie? Prelegentka zaproponowała teologiczne spojrzenie na rolę dóbr materialnych w świecie, w którym żyjemy. Zrozumienie relacji pomiędzy Bogiem a stworzeniem może pomóc lepiej docenić dobra materialne i jednocześnie otworzyć na pomoc materialną bliźnim. Suzy Ismail w wykładzie Zobaczyć drugą stronę: międzywyznaniowe wezwanie do służby stwierdziła, że małżeństwa i rodziny są ponadwyznaniową podstawą społeczności. Przedstawiła muzułmańską wizję rodziny, w której bardzo troszczy się o utrzymywanie pozytywnych więzi rodzinnych i nieustannie poszukuje się sposobów ich wzmocnienia. Aby przeciwdziałać kulturze antymałżeńskiej, proponowała ponadwyznaniowe zaangażowanie chrześcijan i muzułman. W tym kontekście ukazywała wartość dialogu na temat małżeństwa w swojej społeczności, w partnerstwie z innymi wyznaniami, pozwalającego zmierzać do wspólnego celu.

Wreszcie arcybiskup Los Angeles Jose Horacio Gomez w ostatnim wykładzie Dajcie mi waszych utrudzonych, waszych biednych... podjął zagadnienie imigracji. Wskazał, że jako przywódca największej narodowej społeczności katolickiej służy ponad 5 milionom katolików pochodzących z każdego zakątka świata i mówiących ponad 40 językami. Przywołując swoje doświadczenia z Los Angeles oraz swoje własne doświadczenie jako meksykańskiego imigranta, naturalizowanego obywatela, zaprezentował „ludzką twarz” dzisiejszej imigracji. Ponadto przedstawił okrutny wpływ załamanego amerykańskiego systemu imigracji na rodziny i dzieci oraz wyjaśniał, że reformy są konieczne, aby bronić praw człowieka i odnowić ducha Ameryki. 


\section{Świadectwo i modlitwa z papieżem Franciszkiem}

Kolejne dwa dni były przeznaczone na spotkanie z ojcem świętym Franciszkiem, który w sobotę wysłuchał świadectw rodzin, zaś w niedzielę przewodniczył mszy świętej celebrowanej dla rodzin z całego świata. Podczas tzw. wieczoru świadectw świadectwa rodzin z wybranych krajów - Australii, Ukrainy, Jordanii, Nigerii, Argentyny i usA - poprzedzone były odczytaniem tekstu wybranej Ewangelii. W odpowiedzi na usłyszane słowa ojciec święty Franciszek powiedział: „Dziękuję tym, którzy złożyli świadectwa. Dziękuję osobom, które obdarzyły nas radością poprzez sztukę, piękno, które jest drogą, aby dotrzeć do Boga. [...]. Dziękuję wszystkim. Tym, którzy nam tutaj przekazali przesłanie, i za waszą obecność, która jest również świadectwem. Prawdziwym świadectwem, że warto żyć w rodzinie, że społeczeństwo rośnie w siłę, rośnie w dobru, rośnie w pięknie i prawdziwie się rozwija, jeśli jest zbudowane na fundamencie rodziny.

Kiedyś pewne dziecko zapytało mnie - a wiecie, że dzieci zadają trudne pytania - «Ojcze, co robił Pan Bóg, zanim stworzył świat?». Zapewniam was, że trudno mi było odpowiedzieć. I powiedziałem mu to, co teraz mówię wam: przed stworzeniem świata Bóg kochał, bo Bóg jest miłością; ale była to taka miłość, jaką Bóg miał w sobie, miłość pomiędzy Ojcem i Synem w Duchu Świętym. Była ona tak wielka, tak obfitująca [...], że nie mógłby być egoistą. Musiał wyjść z siebie, aby mieć kogoś do kochania poza sobą. I wtedy Bóg stworzył świat. Wówczas Bóg stworzył ten cud, w którym żyjemy, a który niszczymy, ponieważ jesteśmy trochę głuptasami. Ale Biblia mówi, że najpiękniejszą rzeczą, jaką uczynił Bóg jest rodzina. Stworzył mężczyznę i kobietę, powierzając im wszystko. Poddał im świat: «Bądźcie płodni i rozmnażajcie się, uprawiajcie ziemię, niech wydaje owoce, niech się rozwija». Całą miłość, jaką zawarł w tym cudownym stworzeniu, powierzył rodzinie”.

W czasie mszy świętej papież Franciszek powiedział m.in., że dla Kościoła rodzina nie jest powodem do obaw, ale raczej radosnym potwierdzeniem Bożego błogosławieństwa dla dzieła stworzenia. Każdego dnia, na całym

\footnotetext{
Przemówienie ojca świętego podczas święta rodziny i modlitewnego czuwania, B. Franklin Parkway, Filadelfia, 26.09.2015, oficjalne tłumaczenie: http://w2.vatican.va/content/francesco/pl/speeches/2015/september/documents/papa-francesco_20150926_usa-festa-famiglie. html.
} 
świecie Kościół może radować się darem Pana, jakim jest tak wiele rodzin, które nawet pośród trudnych prób pozostają wierne swoim obietnicom i dochowują wiary! Za główne wyzwanie duszpasterskie naszych zmieniających się czasów uznał zdecydowane popieranie rodziny, pomimo przeszkód, jakie spotyka -wdzięczność i uznanie powinny przeważać nad obawami i narzekaniami. Bez rodziny, nawet Kościół by nie istniał. Nie mógłby też być tym, do czego jest powołany, to znaczy znakiem i narzędziem wewnętrznego zjednoczenia z Bogiem i jedności całego rodzaju ludzkiego. Na koniec papież ogłosił, że następny światowy Kongres Rodzin odbędzie się w Irlandii.

Miłość to jedna $\mathrm{z}$ najważniejszych wartości, jaką każdy człowiek powinien realizować w życiu. Jest nie tylko darem, ale też zadaniem wszystkich małżeństw i rodzin. Jej ważność wypływa z mocy samego Boga. Przede wszystkim Bóg jest Miłością i tą Miłością dzieli się z człowiekiem. Kongres zakończył się w poczuciu wartości małżeństwa i rodziny, jako najcenniejszej komórki życia społecznego oraz duchowego zjednoczenia z Bogiem. Kościół nieustannie służy rodzinie, towarzyszy na wszystkich etapach jej egzystencji, gdyż pozostaje ona uczestnikiem Jego zbawczego posłannictwa. 